\title{
Rola Agencji Nieruchomości Rolnych w przemianach struktury agrarnej w Polsce
}

\section{Wstęp}

Problemy sektora rolnictwa w Polsce stanowią jedno z najpoważniejszych wyzwań rozwojowych gospodarki narodowej. Rolnictwo, w porównaniu z innymi sektorami gospodarki, w niewielkim stopniu objał proces transformacji.

Przemiany zainicjowało wprowadzenie zasad wolnego rynku bez obudowy prawnej, w tym regulacji niejasnych stosunków własności ziemi. Restrukturyzację sektora rolnictwa rozpoczął proces przekształceń własnościowych, w tym denacjonalizacji. Podjęte decyzje o prywatyzacji państwowych gospodarstw rolnych były szybkie i zdominowane przez teorie neoliberalne, natomiast nie brały pod uwage kwestii makroekonomicznych oraz społecznych. Sposób prywatyzacji miał być wzorowany na doświadczeniach byłej NRD. Instytucją powiernicza, której Skarb Państwa powierzył wykonywanie prawa własności i innych praw rzeczowych w stosunku do mienia państwowego w rolnictwie, została w 1992 r. Agencja Własności Rolnej Skarbu Państwa (AWRSP), której koncepcja była zbliżona do niemieckiego Zakładu Powierniczego Treuhandanstalt. Jej celem było przeprowadzenie restrukturyzacji i prywatyzacji tego mienia zgodnie z przepisami ustawy z dnia 19 października 1991 r. o gospodarowaniu nieruchomościami rolnymi Skarbu Państwa [DzU 1991 Nr 107, poz. 464].

Począwszy od dnia 16 lipca 2003 r. instytucja ta, już jako Agencja Nieruchomości Rolnych (ANR), podjęła nowe powinności wynikające $\mathrm{z}$ ustawy z dnia 11 kwietnia 2003 r. o kształtowaniu ustroju rolnego [DzU $2003 \mathrm{Nr} 64$, poz. 592], realizując jednocześnie dotychczasową misję AWRSP w zakresie restrukturyzacji i prywatyzacji mienia rolnego Skarbu Państwa.

Celem artykułu jest przedstawienie regionalnego zagospodarowania gruntów rolnych z Zasobu Własności Rolnej Skarbu Państwa (WRSP) przez AWRSP, a następnie ANR. Dodatkowo, podjęto próbę określenia związku między alokacją ziemi z Zasobu a regionalnym zróżnicowaniem struktury agrarnej w Polsce, w której skład wchodzi wielkość gospodarstw oraz własność ziemi. 


\section{Rozdysponowanie ziemi z Zasobu WRSP przez jej prywatyzację i dzierźawę}

Spór na temat roli własności $\mathrm{w}$ procesie gospodarowania, $\mathrm{w}$ tym $\mathrm{w}$ rolnictwie, trwa od początków ekonomii klasycznej. Obecne dyskusje w literaturze przedmiotu na temat prywatyzacji koncentrują się na ogół na relatywnych walorach przedsiębiorstw prywatnych i publicznych, spodziewanych korzyściach ze wzrostu efektywności alokacyjnej i technicznej w wyniku prywatyzacji oraz na spadku wydatków budżetowych dzięki likwidacji nieefektywnych przedsiębiorstw państwowych.

Prywatyzacja, jako nieodłączny element transformacji systemowej w Polsce, stanowi narzędzie długofalowej polityki gospodarczej. Jej podstawowym celem jest stworzenie podstaw dla przyspieszenia rozwoju gospodarczego, restrukturyzacji i modernizacji gospodarki. Celem ekonomicznym jest poprawa konkurencyjności i w rezultacie wzrost efektywności gospodarowania. Celem społecznym jest kształtowanie warunków stymulujących tworzenie nowych miejsc pracy dających podstawy do poprawy poziomu życia obywateli. Istotne jest także wzmocnienie funkcji nadzoru właścicielskiego [Ministerstwo... 2003].

Wynika $z$ tego, że w polityce rządu dominuje model rynku i prywatnej własności środków produkcji, zgodnie z założeniem, że w systemie gospodarki rynkowej nie ma miejsca na uprzywilejowanie w dziedzinie produkcji własności państwowej.

Za własnością prywatną przemawia to, iż stanowi ona element wolności ekonomicznej i wolności swobód obywatelskich: Wtasność prywatna lub pewne dysponowanie dobrami zewnętrznymi daja każdemu przestrzeń potrzebna dla autonomii osobistej i rodzinnej i należy je uważać za poszerzenie niejako wolności ludzkiej. Stanowiq one pewne uwarunkowanie swobód obywatelskich, ponieważ pobudzaja do podejmowania obowiqzku i ponoszenia ciężarów [Lisak 2000]. Fakt ten był ważny na początku transformacji gospodarczej, która towarzyszyła demokratyzacji państwa.

Instytucja prywatnej własności wzmaga odpowiedzialność za posiadane dobra. Właściciel, gospodarując na własne ryzyko i odpowiedzialność, pozostaje $\mathrm{w}$ większym stopniu w zgodzie $\mathrm{z}$ zasadami racjonalnego gospodarowania niż najemny administrator, gospodarujący na ryzyko właściciela [Runowski, Ziętara 2002, s. 43].

Dodatkowym aspektem własności, zwłaszcza w odniesieniu do rolnictwa, jest charakter pracy, który łączy się z formą własności. W gospodarstwach rodzinnych, które w Polsce, zgodnie z Konstytucją RP [DzU 1997], są podstawą 
ustroju rolnego państwa, ziemia nie musi w całości stanowić własności rodziny. Wielkość takiego gospodarstwa określa potencjał własnych zasobów pracy. $Z$ chęci pomnożenia własności prywatnej może płynąć inicjatywa i kreatywność rodziny rolnika, która stara się o większą efektywność, rzetelność i satysfakcję, pracując na swoim. Poza tym koszty monitoringu pracy są w tym przypadku zerowe. $Z$ kolei prywatne wielkoobszarowe gospodarstwa rolne, dysponujące ziemią własną bądź z dzierżawy, opierają się przede wszystkim na najemnej sile roboczej.

Niektórzy ekonomiści, jak na przykład Sappington oraz Stiglitz [1987], uważają że nie ma definitywnie nadrzędnej formy własności.

Gillis [1980, s. 272] podkreśla, że straty w wielu przedsiębiorstwach należących do państwa wynikały nie tyle $\mathrm{z}$ ich działalności operacyjnej, ile $\mathrm{z}$ pełnienia przez nie wielu funkcji społecznych (...) z reguły przynależnych agencjom rządowym bądź instytucjom publicznym. Kornai [2000], Berglof i Roland [1998] oraz Frydman i in. [2000] uważaja, że głównym powodem nieefektywności państwowych przedsiębiorstw w krajach komunistycznych były zbyt „miękkie" ograniczenia budżetowe.

Zdaniem autorki, rozważając proces przechodzenia od rolnictwa państwowego do prywatnego, podstawową kwestią jest raczej struktura agrarna niż własność sama w sobie, ale opinie na tẹ temat są oczywiście podzielone. Dla przykładu Michna [2002] opowiada się za oparciem struktury agrarnej na ziemiach północnych i zachodnich na prywatnej własności ziemi. Poglądy te podziela m.in. Runowski [2002, s. 73], według którego posiadanie ziemi na własność nie jest jednak warunkiem niezbędnym do prowadzenia produkcji rolniczej, natomiast zasadne jest utrzymywanie i utrwalanie instytucji dzierżawy i gospodarowanie na gruntach dzierżawionych.

Doświadczenia krajów rozwijających się oraz transformujących swoją gospodarkę wskazuja że nie występuje istotna różnica między prywatnymi a państwowymi gospodarstwami (przedsiębiorstwami) rolnymi, jeśli porównuje się ich efektywność [Millward 1988; Clarke i Pitelis 1993].

W Polsce wyniki rankingu najlepszych gospodarstw i przedsiębiorstw rolnych, powstałych na zrestrukturyzowanych nieruchomościach własności skarbu państwa ${ }^{1}$, wskazuja, że proces prywatyzacji na gruntach skarbowych wspiera efektywność. Gospodarstwa działające na gruntach całkowicie lub częściowo wykupionych charakteryzują się na ogół wyższymi wskaźnikami rentowności działalności gospodarczej, rentowności aktywów ogółem oraz zyskiem w przeliczeniu na 1 ha w porównaniu z przedsiębiorstwami dzierżawionymi, spółkami ANR oraz rolniczymi spółdzielniami produkcyjnymi [Leopold, Ziętara 2004, s. 3-4].

\footnotetext{
${ }^{1}$ Ranking prowadzony jest od 1995 r. z inicjatywy AWRSP (obecnie - ANR), Instytutu Ekonomiki Rolnictwa i Gospodarki Żywnościowej oraz „Nowego Życia Gospodarczego”. Jego podstawą są analizy sytuacji ekonomiczno-finansowej gospodarstw dokonywane przez IERiGŻ.
} 
W procesie transformacji rolnictwa powinno odróżniać się „prywatyzację ziemi", pojmowaną jako transfer ziemi do prywatnych właścicieli dokonywany bez względu na sposób jej przeznaczenia, od ,indywidualizacji rolnictwa", rozumianej jako transfer ziemi do jej indywidualnego użytkowania bez względu na formalne prawa własności [Lerman 2000]. Dzierżawa jest taką forma indywidualizacji.

W Polsce pierwotnym zamiarem ówczesnej AWRSP było sprywatyzowanie całego przejętego majątku, w tym gruntów rolnych. W pierwszych trzech latach działalności Agencji (do 1994 r. włącznie) sprzedano tylko 3\% ogółu przejętych gruntów. W ciagu ponad trzynastu lat funkcjonowania (do 31.03.2005 r.) Agencja sprzedała zaledwie 32\% ogółu przejętych gruntów, natomiast $49 \%$ znajduje się w dzierżawie. Grunty dzierżawione stanowią zdecydowaną większość (ok. 80\%) ziemi pozostającej w Zasobie, a aż 17\% „oczekuje" na rozdysponowanie (tab. 1).

Tabela 1

Zagospodarowanie gruntów Zasobu WRSP wedlug województw (stan z 31.03.2005 r.)

\begin{tabular}{|l|r|r|r|r|r|r|r|}
\hline \multirow{2}{*}{ Województwa } & \multirow{2}{*}{$\begin{array}{c}\text { Grunty } \\
\text { przejęte }\end{array}$} & \multicolumn{2}{|c|}{ sprzedane } & \multicolumn{2}{c|}{$\begin{array}{c}\text { przekazane } \\
\text { W dzierżawe }\end{array}$} & \multicolumn{2}{c|}{$\begin{array}{c}\text { do rozdyspo- } \\
\text { nowania }\end{array}$} \\
\cline { 3 - 8 } & ha & \multicolumn{1}{|c|}{ ha } & \multicolumn{1}{c|}{$\%$} & \multicolumn{1}{c|}{ ha } & \multicolumn{1}{c|}{ ha } & \multicolumn{1}{c|}{ ha } \\
\hline Polska & 4709506 & 1507494 & 32,0 & 2269434 & 48,2 & 473773 & 10,1 \\
\hline Dolnoślaskie & 494585 & 139057 & 28,1 & 264146 & 53,4 & 41903 & 8,5 \\
\hline $\begin{array}{l}\text { Kujawsko- } \\
\text {-pomorskie }\end{array}$ & 270592 & 72599 & 26,8 & 155404 & 57,4 & 2934 & 1,1 \\
\hline Lubelskie & 190409 & 81526 & 42,8 & 66050 & 34,7 & 26782 & 14,1 \\
\hline Lubuskie & 360583 & 99748 & 27,7 & 173705 & 48,2 & 59353 & 16,5 \\
\hline Lódzkie & 79791 & 36454 & 45,7 & 30201 & 37,9 & 6218 & 7,8 \\
\hline Małopolskie & 38925 & 12668 & 32,5 & 15559 & 40,0 & 4216 & 10,8 \\
\hline Mazowieckie & 116965 & 49236 & 42,1 & 35202 & 30,1 & 18039 & 15,4 \\
\hline Opolskie & 184419 & 43882 & 23,8 & 123987 & 67,2 & 8286 & 4,5 \\
\hline Podkarpackie & 151826 & 68939 & 45,4 & 37609 & 24,8 & 21296 & 14,0 \\
\hline Podlaskie & 127890 & 37053 & 29,0 & 60548 & 47,3 & 10999 & 8,6 \\
\hline Pomorskie & 434092 & 172596 & 39,8 & 188589 & 43,4 & 39331 & 9,1 \\
\hline Śląskie & 82982 & 20298 & 24,5 & 43413 & 52,3 & 11747 & 14,2 \\
\hline Świętokrzyskie & 49611 & 19461 & 39,2 & 14616 & 29,5 & 12795 & 25,8 \\
\hline $\begin{array}{l}\text { Warmińsko- } \\
\text {-mazurskie }\end{array}$ & 816007 & 291658 & 35,7 & 376456 & 46,1 & 84828 & 10,4 \\
\hline Wielkopolskie & 497109 & 139721 & 28,1 & 267539 & 53,8 & 28480 & 5,7 \\
\hline $\begin{array}{l}\text { Zachodniopo- } \\
\text { morskie }\end{array}$ & 813720 & 222598 & 27,4 & 416410 & 51,2 & 96566 & 11,9 \\
\hline
\end{tabular}

Źródło: Opracowanie własne na podstawie danych ANR, Zespół Gospodarowania Zasobem. 
Ministerstwo Skarbu oceniało wartość gruntów w Zasobie WRSP na 12 mld zł (grudzień 2001 r.), co dało przeciętnie ok. 4,15 tys. zł za 1 ha.

Przepływ ziemi jest regionalnie zróżnicowany i związany ze znaczeniem sektora uspołecznionego $\mathrm{w}$ rolnictwie $\mathrm{w}$ okresie przed transformacją. Około $80 \%$ ziemi w Zasobie WRSP pochodziło z byłych PGR-ów. Grunty przejęte do Zasobu WRSP w relacji do ogółu gruntów przypadających na gospodarstwa rolne w Polsce stanowiły ok. $28 \%$. Udział ten był najwyższy w województwach: zachodniopomorskim, lubuskim i warmińsko-mazurskim, natomiast najniższy odpowiednio w województwach: małopolskim, mazowieckim oraz łódzkim. Odnosząc grunty Zasobu WRSP do ogólnej powierzchni UR, ich udział wynosił $26 \%$, a w stosunku do UR w gospodarstwach indywidualnych $30,7 \%$.

Średnio w kraju ok. $60 \%$ gruntów przejętych do zasobu WRSP nadal w nim pozostaje, natomiast w takich województwach jak dolnośląskie, opolskie, śląskie i zachodniopomorskie w dyspozycji Agencji znajduje się wciąż $2 / 3$ lub więcej przejętej ziemi. Większość stanowią grunty przekazane w dzierżawę. (tab. 1).

W zależności od regionu różnie kształtują się proporcje między powierzchnią sprzedanej i dzierżawionej ziemi. Znaczną przewagę dzierżawy nad sprzedażami w relacji do średniego wskaźnika krajowego $(1,51)$ można zauważyć w województwach: opolskim $(2,83)$, kujawsko-pomorskim i śląskim $(2,14)$, wielkopolskim $(1,91)$ oraz dolnośląskim $(1,90)$. Wyjątkowa przewaga sprzedaży nad dzierżawami, w porównaniu ze średnią relacją w kraju $(0,66)$, wystappiła w województwach: podkarpackim $(1,83)$, mazowieckim $(1,40)$, świętokrzyskim $(1,33)$, lubelskim $(1,23)$ oraz lódzkim $(1,21)$.

W celu ukazania regionalnego zróżnicowania rozdysponowania ziemi z Zasobu WRSP zastosowano analizę skupień (klastrów) techniką minimalizacji wariancji Warda. Obiekty (województwa) jednego skupienia powinny być jednorodne w stosunku do cech charakterystycznych, wyjaśniających właściwości tego skupienia. Wybrane cechy (składowe) to grunty: przejęte do Zasobu, sprzedane, przekazane w dzierżawę oraz do rozdysponowania. W procedurach grupowania, czyli sekwencyjnego zmniejszania liczby obiektów przez łączenie ich w grupy wyższego rzędu, istnieje możliwość graficznego przedstawienia wyników grupowania w postaci dendrogramu (rys. 1).

Drzewko połączeń ilustruje kolejne połączenia skupień coraz to wyższego rzędu. Uzyskana hierarchia pozwala na określenie wzajemnego położenia skupień i obiektów w nich zawartych. Na podstawie obliczeń modelowych stwierdzono, że województwa mogą być przypisane do jednej grupy podobieństwa, jeśli odległość euklidesowa między nimi jest mniejsza od 0,8. Rysunek 1 wskazuje na dwie grupy podobieństwa województw; w pierwszej znajduje się 11, a w drugiej 5 województw. 


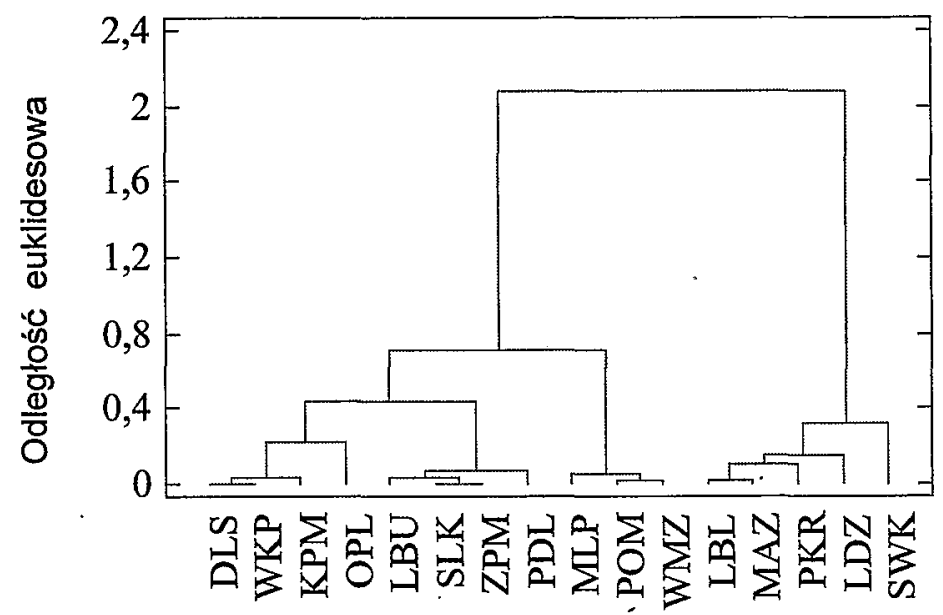

\section{Rysunek 1}

Analiza skupień 16 województw według zagospodarowania gruntów z Zasobu WRSP Żródło: Opracowanie własne na podstawie danych ANR, Zespół Gospodarowania Zasobem.

$\mathrm{Z}$ tabeli 2 wynika, że czynnikami statystycznie istotnie różnicującymi dwie wyodrębnione grupy była powierzchnia gruntów przejętych do zasobu oraz przekazanych w dzierżawę.

\section{Tabela 2}

Regionalne zróżnicowanie zagospodarowania gruntów Zasobu WRSP - zestawienie statystyki

\begin{tabular}{|c|c|c|c|c|c|c|c|c|c|c|c|c|c|c|c|c|}
\hline \multirow{2}{*}{ 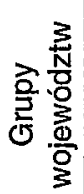 } & \multicolumn{4}{|c|}{$\begin{array}{c}\text { Grunty przejęte } \\
\text { do Zasobu }\end{array}$} & \multicolumn{4}{|c|}{$\begin{array}{c}\text { Grunty } \\
\text { sprzedane }\end{array}$} & \multicolumn{4}{|c|}{$\begin{array}{c}\text { Grunty przekazane } \\
\text { w dzierżawe }\end{array}$} & \multicolumn{4}{|c|}{$\begin{array}{l}\text { Grunty do } \\
\text { rozdysponowania }\end{array}$} \\
\hline & $n$ & $\bar{x}$ & & $s_{\bar{x}}$ & $n$ & $\overline{\mathbf{x}}$ & & $s_{\bar{x}}$ & $n$ & $\bar{x}$ & & $\mathrm{~s}_{\overline{\mathrm{x}}}$ & $n$ & $\bar{x}$ & & $s_{\bar{x}}$ \\
\hline 1 & 11 & 383,9 & a & 66,6 & 11 & 120,0 & $a$ & 21,7 & 11 & 189,3 & a & 33,7 & 11 & 37,5 & a & 8,0 \\
\hline 2 & 5 & 97,3 & $b$ & 98,8 & 5 & 37,4 & $a$ & 32,2 & 5 & 37,4 & $b$ & 49,9 & 5 & 12,2 & a & 11,9 \\
\hline
\end{tabular}

$\mathrm{n}$ - liczba województw, $\overline{\mathrm{x}}$ - średnia wartość badanej cechy [tys. ha], wystapienie identyçznej litery $w$ dwóch porównywanych grupach oznacza brak istotności różnic między grupami przy $p \leq 0,05, s_{\bar{x}}-$ błąd standardowy średniej

Źródło: Badania własne. 


\section{Związek między rozdysponowaniem Zasobu WRSP a powierzchnią gospodarstw rolnych w ujęciu regionalnym}

ANR do marca 2005 r. sprzedała z Zasobu WRSP 1507,5 tys. ha gruntów, natomiast kolejne 2269,4 tys. ha przekazała w dzierżawę. Biorąc pod uwagę te dwa sposoby zagospodarowania ziemi, prawie $2 / 3$ gruntów z Zasobu w całej Polsce przypada na pięć województw: warmińsko-mazurskie, zachodniopomorskie, wielkopolskie, dolnośląskie oraz pomorskie. $Z$ kolei zaledwie 7,3\% znajduje się w pięciu województwach (małopolskie, świętokrzyskie, śląskie, łódzkie i mazowieckie) gdzie rozdysponowano przez sprzedaż i dzierżawę najmniej ziemi (rys. 2).

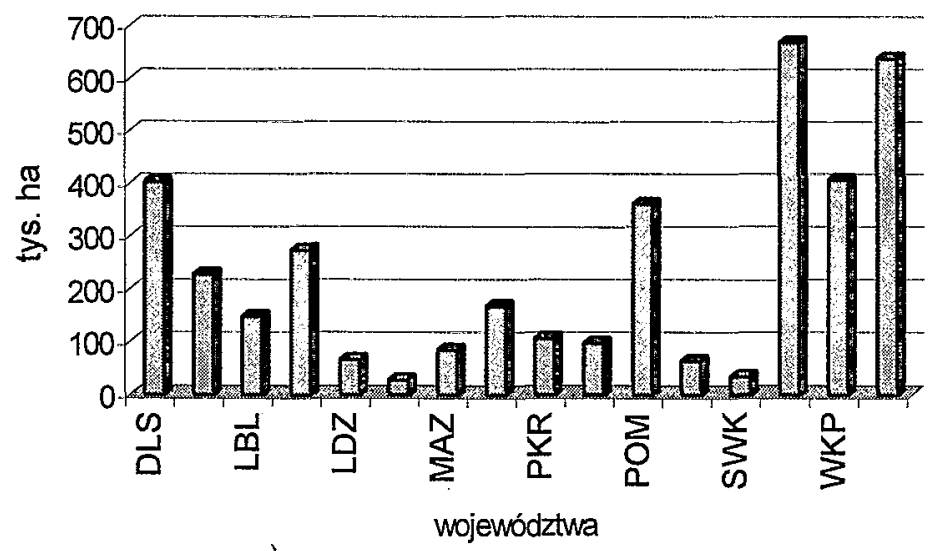

\section{Rysunek 2}

Grunty Zasobu WRSP sprzedane i przekazane w dzierżawę według województw (stan z końca marca 2005 r.)

Źródło: Opracowanie własne na podstawie danych ANR, Zespół Gospodarowania Zasobem.

$\mathrm{Na}$ terenach ziem północnych i zachodnich, gdzie położona jest większość gruntów rolnych Zasobu WRSP, a zwłaszcza te, które pochodzą z byłych PGR, proces restrukturyzacji i prywatyzacji znacząco przyczynił się do poprawy struktury obszarowej prywatnych gospodarstw rolnych. Rezultatów takich nie można było osiagnąć w regionach południowej i środkowej Polski, gdzie udział gruntów rolnych Skarbu Państwa był znikomy [Prywatyzacja... 2005].

Stosunkowo mało ziemi byłych PGR zostało jednak przeznaczone na tworzenie rolniczych gospodarstw rodzinnych. Zdaniem Michny [2002], nie jest obiektywny pogląd, że nie było chętnych rolników indywidualnych na powięk- 
szenie swoich gospodarstw. Idea tworzenia dzierżawnych wielkoobszarowych gospodarstw była dominująca $\mathrm{w}$ polityce rolnej $\mathrm{z}$ początków transformacji, a dopiero później ustępowała potrzebie tworzenia gospodarstw rodzinnych.

W 2002 r. największe, pod względem średniej statystycznej powierzchni, gospodarstwa rolne występowały w województwach: zachodniopomorskim, pomorskim oraz kujawsko-pomorskim, najmniejsze zaś w województwach: małopolskim, śląskim i podkarpackim (rys. 3).

W całym kraju gospodarstwa powyżej 15 ha UR stanowią około $10 \%$ ogółu, a w ich posiadaniu znajduje się 40\% UR. Wielkoobszarowe gospodarstwa rolne, za które w Polsce przyjęło się uważać podmioty mające powyżej 100 ha ziemi, zajmuja około $1 / 5(21,5 \%)$ UR. W grupie tej blisko połowa $(9,6 \%)$ jest w gospodarstwach o powierzchni od 200 do 500 ha, natomiast $1,72 \%$ użytkowanych rolniczo gruntów posiadają gospodarstwa o powierzchni ponad 1000 ha [W Unii... 2004].

Duże gospodarstwa, które powstały w wyniku prywatyzacji ziemi lub jej dzierżawy z Zasobu Agencji, są dziś głównymi beneficjentami wspólnej polityki rolnej oraz mechanizmu rynkowego na bazie kryteriów konkurencyjności UE [Crescenzi 2004, s. 7].

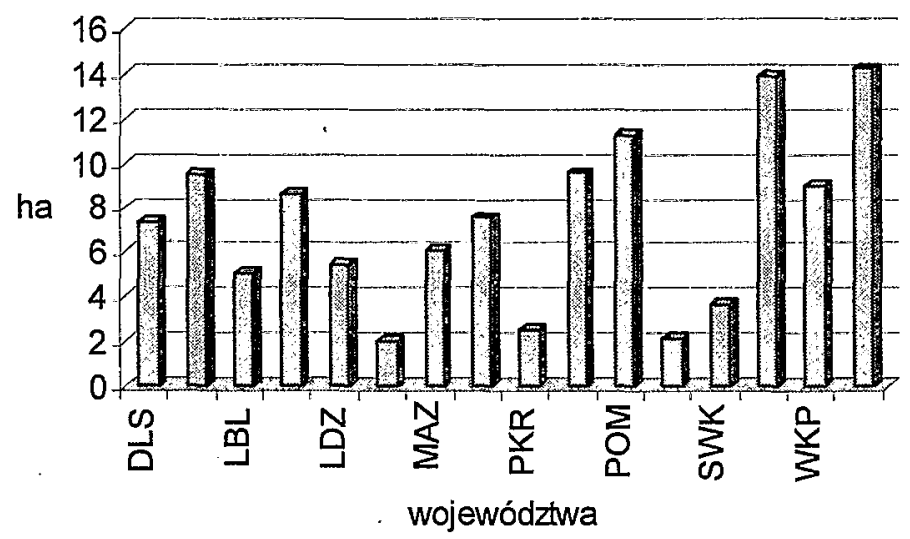

\section{Rysunek 3}

Przeciętna powierzchnia gospodarstw rolnych według województw (2002)* Źródło: Opracowanie własne na podstawie danych ANR, Zespół Gospodarowania Zasobem.

Wystapiła bardzo wysoka, statystycznie istotna korelacja między powierzchnią ziemi sprzedanej i oddanej $\mathrm{w}$ dzierżawę $\mathrm{z}$ Zasobu WRSP a średnią powierzchnią gospodarstwa rolnego $(\mathrm{R}=0,856)$ wyznaczona dla zbioru województw.

"Łącznie z gospodarstwami o powierzchni do 1 ha. 
Do oszacowania przeciętnej zależności między średnią powierzchnią gospodarstwa (zmienna zależna) a powierzchnią gruntów sprzedanych bądź przekazanych w dzierżawę (zmienna niezależna) w poszczególnych województwach zastosowano regresję liniową. Wyniki estymacji przedstawia tabela 3.

\section{Tabela 3}

Wyniki estymacji funkcji regresji liniowej

\begin{tabular}{|l|c|c|c|c|}
\hline Wyszczególnienie & Współczynniki & $\begin{array}{c}\text { Błąd } \\
\text { standardowy }\end{array}$ & t Stat & Wartość-p \\
\hline Przecięcie & 3,6247 & 0,799 & 4,56 & 0,000466 \\
\hline Zmienna $x$ & 0,0016 & 0,00026 & 6,20 & $2,33 E-05$ \\
\hline $\mathrm{R}^{2}=0,73 \mathrm{AR}^{2}=0,71$ & $\mathrm{~F}=38,4$ & \\
\hline
\end{tabular}

$x$ - ziemia sprzedana i oddana $w$ dzierżawę $z$ Zasobu WRSP (tys. ha)

Źródło: Opracowanie własne na podstawie danych ANR, Zespół Gospodarowania Zasobem.

Przeciętna powierzchnia (ha) gospodarstwa w poszczególnych województwach $(y)$ oraz areał ziemi (tys. ha) sprzedanej i oddanej w dzierżawę z Zasobu WRSP $(x)$ związane są ze sobą równaniem regresji liniowej o postaci szczegółowej: $y=3,6247+0,0016 x$

$$
[0,799] \quad[0,00026]
$$

Według ANR, przekształcenia strukturalne powiodły się [Siewierski 2004]. Zdaniem autorki, Agencja, zarządzając gruntami Zasobu WRSP, a przez to pośrednio kształtując strukturę agrarna, zwłaszcza w regionach, gdzie jest głównym graczem na rynku ziemi, powinna mieć na uwadze przewage gospodarstw rodzinnych nad wielkoobszarowymi. Przewaga ta wynika przede wszystkim z [Hardt 2004]:

- $\quad$ wykorzystania głównie własnych zasobów pracy (właściciel i jego rodzina);

- odpowiedniej struktury bodźców (właściciel ma zawsze większą motywację do pracy niż pracownik najemny);

- $\quad$ szybszego dostosowywania się do popytu zgłaszanego przez rynek;

- wytwarzania specyficznych dóbr publicznych (wiejski krajobraz);

- małej uciążliwości dla środowiska (mniejsze zużycie nawozów, ekstensywna produkcja).

\section{Podsumowanie}

Największe rozdrobnienie rolnictwa pod względem obszarowym występuje w południowej i środkowej Polsce, gdzie odsetek gruntów rolnych Skarbu Państwa w dyspozycji badanej Agencji był niewielki. Rola ANR w. zakresie po- 
prawy struktury obszarowej rolnictwa indywidualnego była więc w tym przypadku ograniczona zasobami ziemi. W wyniku analizy stwierdzono jednak ścisłą korelację między wielkością gruntów rozdysponowanych przez Agencję w drodze sprzedaży bądź dzierżawy a przeciętną powierzchnią gospodarstwa dla zbioru szesnastu województw.

Transformacja rolnictwa w Polsce, w której uczestniczy ANR, wbrew wcześniejszym zamierzeniom, nie została jeszcze zakończona. Przemiany agrarne w rolnictwie są procesem powolnym i będą zależeć od dalszej działalności ANR, między innymi od jej interwencji w obrót ziemią rolnicza, którą określa nowa ustawa o ksztaltowaniu ustroju rolnego. Dyskusyjne natomiast pozostaje, czy rolą agencji rządowej jest występowanie w funkcji podmiotu oferującego podaż ziemi na rynku dzierżawy. Dzierżawa jest wprawdzie popularną formą użytkowania ziemi w krajach UE, ale dotyczy ziemi prywatnej. Dzierżawa mienia skarbowego powinna być etapem pośrednim do pełnej jego prywatyzacji.

Nie podważając znaczenia ANR w przemianach struktury agrarnej.w Polce, należy jednak pamiętać, że są one możliwe wyłącznie przy sprzyjającej sytuacji makroekonomicznej kraju oraz właściwie określonych przez państwo stabilnych i prostych ,regułach gry”.

\section{Literatura}

BERGLOF E., ROLAND G., 1998: Soft Budget Constraints and Banking in Transition Economies, Journal of Comparative Economics, 26, s. 18-40.

Clarke T., Pitelis C. (ed.), 1993: The Political Economy of Privatisation. Wydaw. Routledge London.

CRESCENZI R., 2004: EU Agricultural Policy and the regional differentiation of agriculture in Poland. Paper for the International Conference "Europe at the margins: EU regional Policy, peripherality and rurality", 15-16 April 2004, Angers, France.

FRYDMAN R., GRAY CH.W., HESSEL M., RAPACZYNSKI A., 2000: The Limits of Discipline: Ownership and Hard Budget Constraints in the Transition Economies, C.V. Starr Center for Applied Economics working paper, NYU, New York.

GILLIS M., 1980: The Role of State Enterprises in Economic Development. Social Research, Vol. 47, No. 2, s. 248-289.

HARDT Ł., 2004: Nowa polityka rolna w poszerzonej Unii Europejskiej. Raport Instytutu Sobieskiego, Warszawa.

Konstytucja Rzeczypospolitej Polskiej z dnia 2 kwietnia 1997 r. (DzU z dnia 16 lipca 1997 r.), art. 23.

KORNAI J., 2000: Ten Years after 'The Road to a Free Economy: The Author's Self Evaluation, Working paper, Harvard University, Cambridge, MA. 
LEOPOLD A., ZIĘTARA W., 2004: Ranking po 10 latach. Nowe Życie Gospodarcze nr 20. Dodatek „Lista 300 najlepszych gospodarstw rolnych w 2003 r.”, s. 3-4.

LERMAN Z., 2000: Status of Land Reform and Farm Restructuring in Central and Eastern Europe: A Regional Overview. World Bank Technical Paper No. 465, Europe and Central Asia Environmentally and Socially Sustainable Development Series: Structural Change in the Farming Sectors in Central and Eastern Europe Lessons for EU-Accession (Ed. Csaba C., Lerman Z.), Second World Bank/FAO Workshop, June 27$-29,1999$, s. 3-21.

LISAK M., 2000: Bogactwo bez grzechu. Magisterium Kościoła na temat własności, $W$ drodze nr 5 (321).

MICHNA W., 2002: Dyskusja. [w:] Przekształcenia własnościowe w rolnictwie - 10 lat doświadczeń. Materiały konferencyjne, Wydaw. SGGW, s. 40-41.

MILLWARD R., 1988: Measured Sources of Inefficiency in the Performance of Private and Public Enterprises in LDCs [w:] Cook P. Kirkpatrick C. (eds.): Privatization in Less Developed Countries, Brighton: Wheatsheaf.

MINISTERSTWO SKARBU PAŃSTWA, 2003: Ocena przebiegu prywatyzacji majattku skarbu państwa w 2002 roku, Warszawa 2003.

Prywatyzacja gruntów Zasobu WRSP w ujęciu regionalnym. ANR, Warszawa 2005.

SAPPINGTON D., STIGLITZ J., 1987: Privatization, Information, and Incentives, Journal of Policy Analysis and Management, No 6, s. 567-582.

SIEWIERSKI Z., 2004: Przekształcenia strukturalne powiodły się. Nowe Życie Gospodarcze nr 20. Dodatek „Lista 300 najlepszych gospodarstw rolnych w 2003 r.”, s. 2.

RUNOWSKI H., ZIETTARA W., 2002: Stan dotychczasowy i rekomendacja na przyszłość w procesie przekształceń własnościowych. [w:] Przekształcenia własnościowe w rolnictwie - 10 lat doświadczeń. Materiały konferencyjne, Wydaw. SGGW, s. 43-70.

Ustawa z dnia 11 kwietnia 2003 o kształtowaniu ustroju rolnego, DzU $2003 \mathrm{Nr}$ 64, poz. 592.

Ustawa z dnia 19 października 1991 r. o gospodarowaniu nieruchomościami rolnymi Skarbu Państwa, DzU 1991 Nr 107, poz. 464.

W Unii Europejskiej nie lubią latyfundystów. Boss Rolnictwo nr 21, 22.05.2004.

\section{Role of the Agricultural Property Agency in Agrarian Structure Changes in Poland}

\section{Abstract}

The restructuring and privatisation in Poland's state sector of agriculture was (in 1991) entrusted to the Agricultural Property Agency of the State Treasury (hereafter Agricultural Property Agency). The agency was expected to play an important role in the state agricultural policy as far as structural and ownership transformation of the Polish agriculture is concerned. Almost $80 \%$ 
of land in the Treasury Agricultural Property Stock was taken over from former state-owned farms, asymmetrically concentrated in northern and western provinces. The purpose of liquidation of state farms was intended to strengthen the model of family farms chosen by the Government, mainly through privatisation of state land. In fact, till present the agency has sold merely one third of the land in its stock. The lease remains the dominant form applied in management of land, comprising approximately 2 million ha in permanent use among individual farmers and companies.

This paper empirically explores the impacts of APA on agrarian structure in Poland. The study results show statistically significant strong correlation between regionally distributed property in the form of land sale/land lease and the average area of individual farms. 